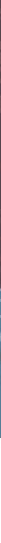

\title{
Fields of education, gender and the labour market
}

- There are gender differences in many fields of education: women are over-represented in Teacher training and education science, and in Health and welfare courses while men are over-represented in Engineering, manufacturing and construction.

- The fields of education with a larger share of female graduates are also those whose graduates have lower employment rates and lower earnings, while employment rates and earnings are higher in Engineering, manufacturing and construction, a field studied by only $7 \%$ of women.

- Even within the same field of education, employment rates and earnings are generally higher for men than for women, partly due to the different types of jobs and responsibilities men and women hold. For example, for those who studied Health and welfare women are more likely than men to work in nursing.

More and more adults are earning a tertiary qualification, but not all tertiary degrees have the same value on the labour market. In general, postgraduate degrees such as master's and doctoral degrees are associated with higher employment rates and earnings than bachelor's degrees. Labour market outcomes also vary by field of education. Some fields of education differ markedly in their gender composition, reflecting the sex-typing of occupations and gender stereotypes. Graduates' field of education is closely related with their occupational choices; therefore a better understanding of gender disparities in this area can help to identify some of the mechanisms that lie behind gender differences in the labour market and beyond (OECD, 2016a).

Figure 1. Distribution of fields of education studied among tertiary-educated adults, by gender (2012 or 2015)

Survey of Adult Skills, 25-64 year-old non-students, average

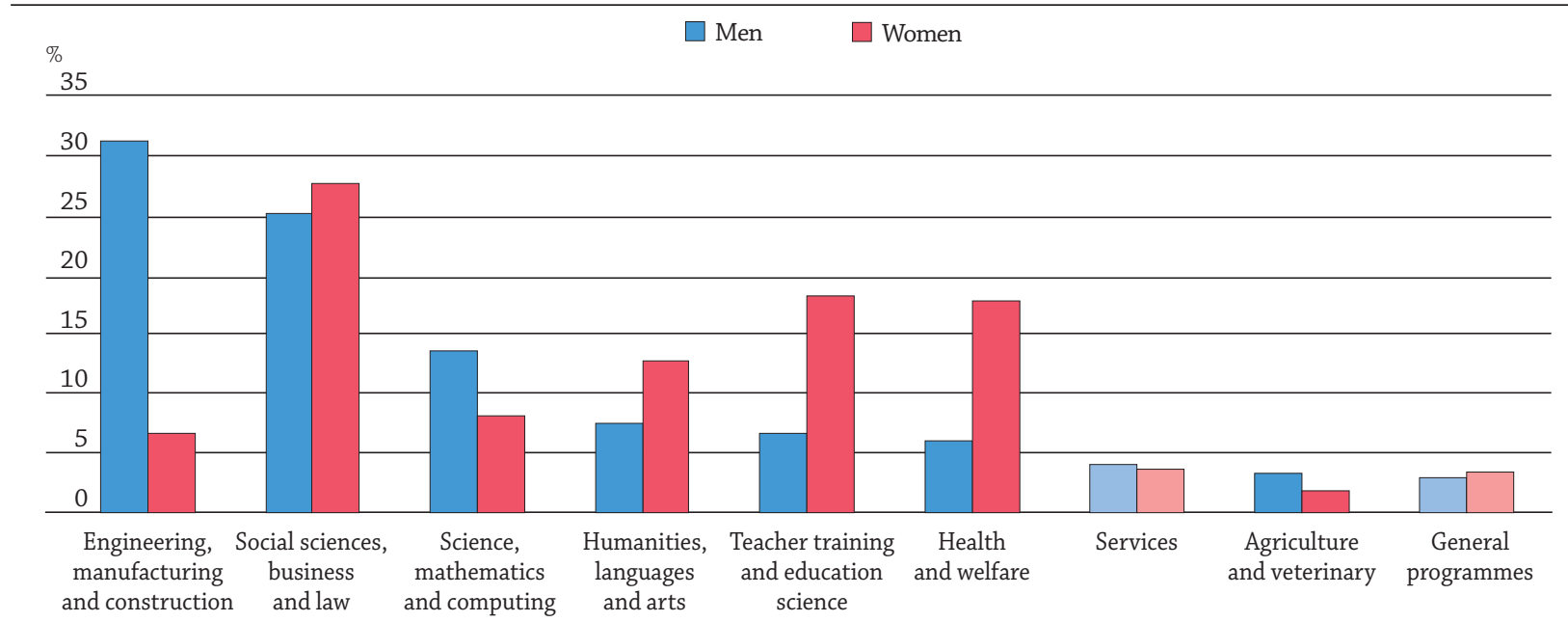

Notes: Different year of reference for countries, see explanations in the textbox. Differences between genders are not statistically significant at $5 \%$ for the fields of Services and General programmes, thus, these fields are represented in a lighter shade.

Fields of education are ranked in descending order of the share of men who studied in this specific field.

Source: OECD (2012, 2015), Survey of Adult Skills (PIAAC), www.oecd.org/skills/piaac/publicdataandanalysis. 


\section{What are the most popular fields in tertiary education?}

The Survey of Adult Skills, a product of the OECD Programme for the International Assessment of Adult Competencies (PIAAC), found that on average the most popular fields of education at tertiary level are Social sciences, business and law (27\% of all students), Engineering, manufacturing and construction (18\%), Teacher training and education science (13\%), Health and welfare (12\%), and Science, mathematics and computing (11\%). In contrast, less than $5 \%$ of tertiary-educated adults had studied Agriculture and veterinary, General programmes, and Services.

However, gender differences are stark. Men are most likely to study Engineering, manufacturing and construction (31\%), which attracted only $7 \%$ of women. Large gender differences are also seen in Teacher training and education science, and in Health and welfare where the share of women who studied in these fields is more than twice the share among men (Figure 1).

Among the OECD countries and subnational entities that participated in the Survey of Adults Skills, most have more tertiary-educated adults with Engineering, manufacturing and construction degrees than with Teacher training and education science ones. In all countries, without exception, more men than women have a qualification in Engineering, manufacturing and construction.

\section{Countries and fields of education covered in the Survey of Adult Skills}

The data source for this publication is the Survey of Adult Skills. This survey was not specifically designed to analyse the tertiaryeducated population, so the sample size for specific fields of education can be small and should therefore be interpreted with caution.

The national and subnational entities included in this analysis are Australia, Austria, Canada, the Czech Republic, Denmark, Estonia, England (United Kingdom), Finland, Flanders (Belgium), France, Germany, Ireland, Italy, Japan, Korea, the Netherlands, Northern Ireland (United Kingdom), Norway, Poland, the Russian Federation, the Slovak Republic, Spain, Sweden, the United States, for 2012, and Chile, Greece, Israel, Lithuania, New Zealand, Singapore, Slovenia and Turkey, for 2015.

The nine fields of education analysed in PIAAC are reflected in Figure 1. These fields of education are aggregated at a broad level in order to compare them at the international level and have sufficient observations to draw policy-relevant conclusions. This aggregation has a downside which is that the broad groups often combine fields of education with very different profiles and different labour market outcomes. The interpretation of the results is therefore not reflecting the full complexity and specificity of each programme.

\section{Graduates' field of education affects the employment outcomes}

In general, tertiary-educated adults have higher employment rates than adults with lower education levels, but some differences exist across fields of education at the tertiary level. Across countries, $88 \%$ of the adults who studied Engineering, manufacturing and construction are employed; six percentage points more than for adults who studied Humanities, languages and arts, and Teacher training and education science. These differences could be partially explained by the gender composition, since a larger share of women - who typically have larger inactivity rates than men - studied the fields with lower employment rates (Figure 2).

Differences in the gender composition of different professions may also explain gender differences in employment rates for each field of education. For example, within Health and welfare, men and women tend to specialise in different subjects and choose different professions. Almost half of all doctors on average across OECD countries are women, but in Europe and the United States, women are about ten times more likely than men to work in nursing, a profession with relatively low retention rates. This difference in the gender composition may contribute to the large gender difference in employment rates among those who studied Health and welfare (OECD, 2015; OECD, 2016b).

Some fields of education are more attractive in terms of earnings than others, but gender differences persist

Overall, individuals who studied in fields that are associated with higher employment rates tend to also have higher earnings than the average for tertiary-educated adults. Conversely, Teacher training and education science, and Humanities, language and arts graduates have lower employment rates and also tend to command lower earnings. 
Figure 2. Employment rates of tertiary-educated adults, by field of education studied and gender (2012 or 2015)

Survey of Adult Skills, 25-64 year-old non-students, average

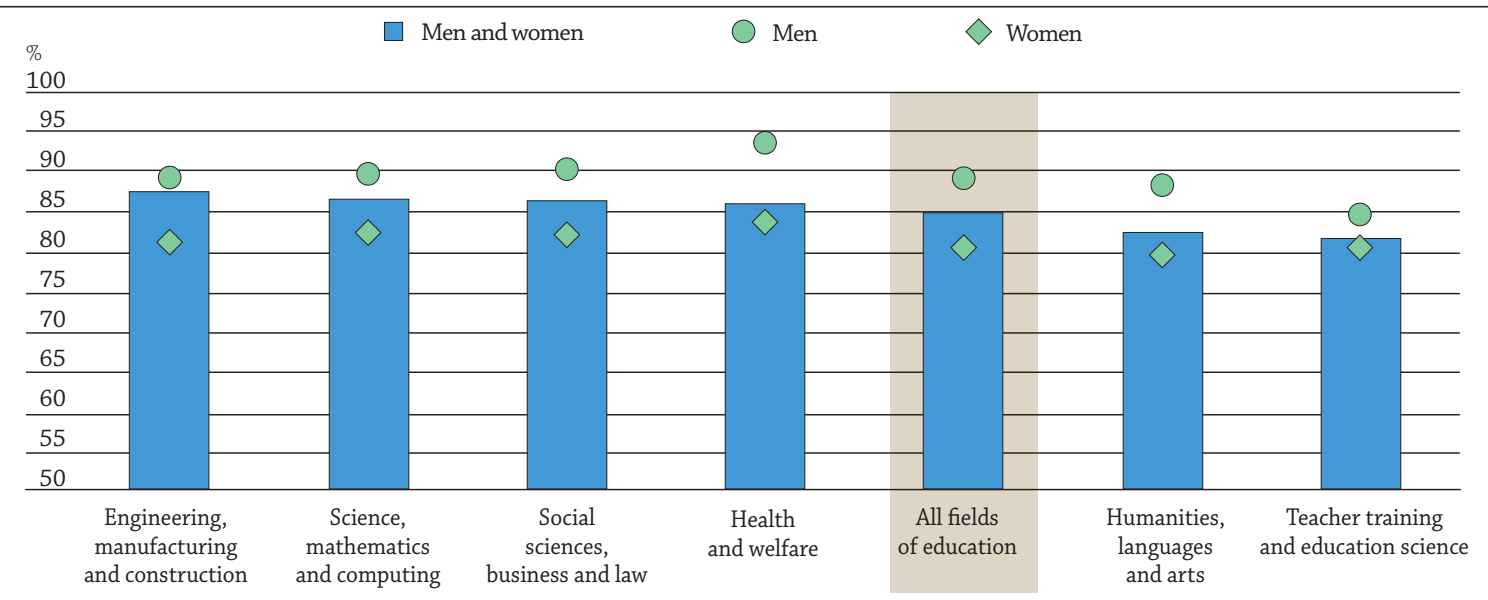

Notes: Different year of reference for countries, see explanations in the textbox.

Fields of education are ranked in descending order of the percentage of employed tertiary-educated adults who studied in that field.

Source: OECD (2012, 2015), Survey of Adult Skills (PIAAC), www.oecd.org/skills/piaac/publicdataandanalysis.

The fields of education offering graduates higher earnings are Engineering, manufacturing and construction, Socialsciences, business and law, and Science, mathematics and computing. On average, among the OECD countries and subnational entities that participated in the Survey of Adult Skills, workers who studied these fields at the tertiary level earn about $10 \%$ more than the average of tertiary-educated earners for full-time work. Full-time earnings among workers who studied in Health and welfare are close to average earnings, while the average earnings of those who graduated in Teacher training and education science, and Humanities, language and arts are about 15\% lower than the average.

Figure 3. Differences in earnings between female and male workers among those who studied Social sciences, business and law (2012 or 2015)

Survey of Adult Skills, 25-64 year-old non-student full-time workers; women's earnings as a percentage of men's earnings

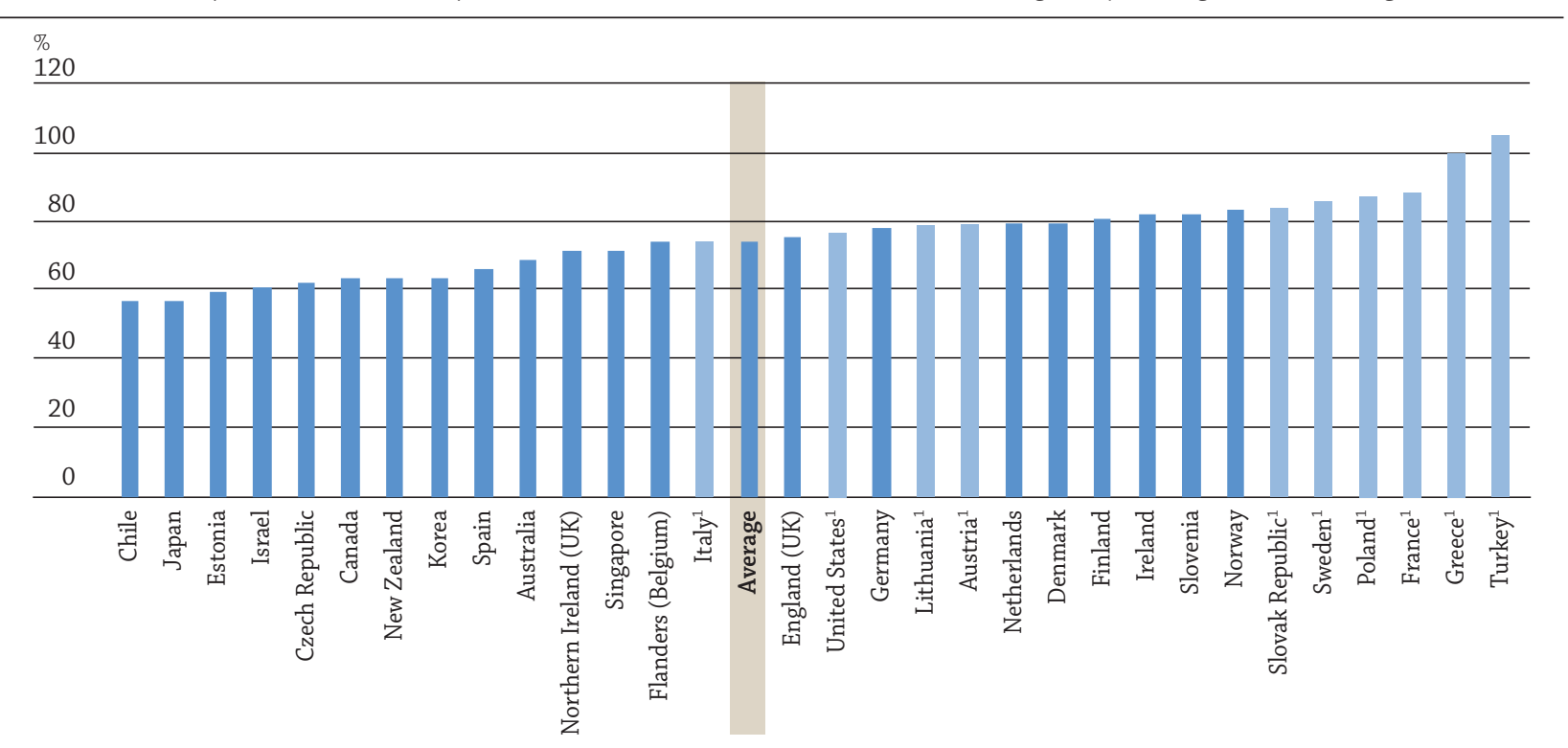

Notes: Different year of reference for countries, see explanations in the textbox.

1. The difference between earnings of men and women is not statistically significant at $5 \%$ (lighter tone).

Countries and subnational entities are ranked in ascending order of the earnings of women as a percentage of men's earnings.

Source: OECD (2012, 2015), Survey of Adult Skills (PIAAC), www.oecd.org/skills/piaac/publicdataandanalysis. 


\section{EDUCATION INDICATORS IN FOCUS}

education data education evidence education policy education analysis education statistics

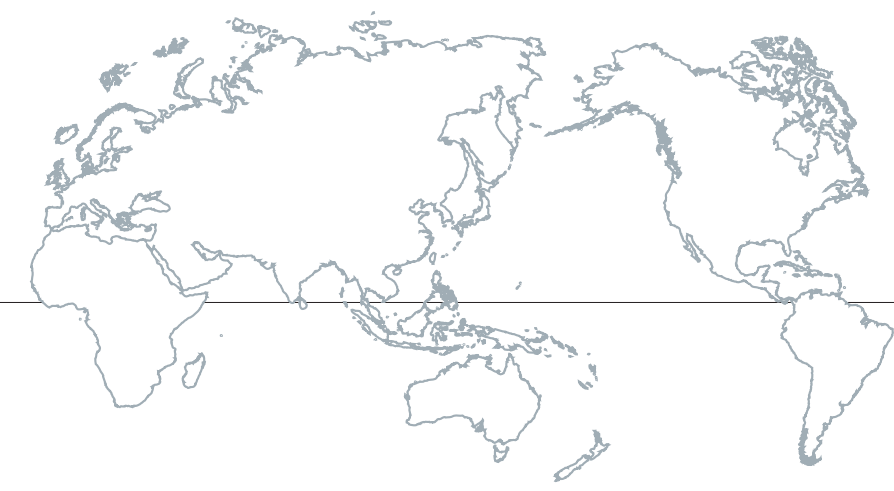

A larger share of men than women studied in fields of education that are associated with higher earnings, such as Engineering, manufacturing and construction, and Science, mathematics and computing, while a higher share of women studied in fields associated with lower earnings including Teacher training and education science, and Humanities, languages and arts.

Women tend to earn less even if they studied in the same field of education as men, and the share of women who study a specific field of education influences the average earnings among men and women who studied this field. For example, in Social sciences, business and law, which was studied by a relatively large share of both women and men and is associated with relatively high earnings, on average across OECD countries and subnational entities that participated in the Survey of Adult Skills, women earn only about $75 \%$ as much as men (Figure 3).

Fields of education are divided into a number of different specialisations and cross-country variations and differences in earning gender gaps may also be related to differences in the specific specialisation studied and the professions chosen subsequently. For example, doctors - who earn high remuneration - represent about $5 \%$ of the health and social sector workforce (OECD, 2016c). Although women make up 45\% of doctors on average across OECD countries (OECD, 2015), $18 \%$ of women studied Health and welfare compared with only $6 \%$ of men. Therefore a large number of women who studied in this field of education are likely to be working in other, lower-paid professions within the sector, such as nursing and long-term care. Other factors may also explain differences in earnings across countries and differences between men and women within countries, such as the sectors where they work after completing tertiary education, the types of occupation (such as management positions) and the types of contracts (OECD, 2016d).

The bottom line: The choice of field of education is rooted in the educational and personal experiences people have prior to reaching tertiary education. The acute gender segregation that is observed in some fields of education is likely to pave the way for grave imbalances in the labour market performance of men and women. Education fields with a larger share of women are typically associated with lower employment rates and lower earnings. However, even within the same field of education, employment rates and earnings are generally higher for men than for women. Inclusive labour markets and societies can only be achieved through long-term comprehensive and concerted actions.

\section{For more information}

- OECD (2016a), Education at a Glance 2016: OECD Indicators, OECD Publishing, Paris, http://dx.doi.org/10.1787/eag-2016-en.

- OECD (2016b), Health Workforce Policies in OECD Countries: Right Jobs, Right Skills, Right Places, OECD Health Policy Studies, OECD Publishing, Paris, http://dx.doi.org/10.1787/9789264239517-en.

- OECD (2016c), "Health status", OECD Health Statistics (database), http://stats.oecd.org/index.aspx?DataSetCode=HEALTH_STAT.

- OECD (2016d), OECD Employment Outlook 2016, OECD Publishing, Paris, http://dx.doi.org/10.1787/empl_outlook-2016-en.

- OECD (2015), Health at a Glance 2015: OECD Indicators, OECD Publishing, Paris, http://dx.doi.org/10.1787/health_glance-2015-en.

\section{Contact}

Gara Rojas González (Gara.RojasGonzalez@oecd.org), Simon Normandeau (Simon.Normandeau@oecd.org), Rie Fujisawa (Rie.Fujisawa@oecd.org)

\section{Visit}

www.oecd.org/education/education-at-a-glance-19991487.htm

Education Indicators in Focus (previous issues)

PISA in Focus

Teaching in Focus

Photo credit: @ Ghislain \& Marie David de Lossy/Cultura/Getty Images

This paper is published under the responsibility of the Secretary-General of the OECD. The opinions expressed and arguments employed herein do not necessarily reflect the official

views of OECD member countries. to the name of any territory, city or area.

The statistical data for Israel are supplied by and are under the responsibility of the relevant Israeli authorities. The use of such data by the OECD is without prejudice to the status of the Golan Heights, East Jerusalem and Israeli settlements in the West Bank under the terms of international law. 